\title{
Tolerance of piava juveniles to different ammonia concentrations
}

\section{Tolerância de juvenis de piava para diferentes concentrações de amônia na água}

\author{
Carlos Eduardo Copatti ${ }^{*}$; Keidi Carolina dos Santos Bolner ${ }^{2}$; \\ Felipe Link de Rosso ${ }^{2}$; Vania Lucia Loro ${ }^{3}$; Bernardo Baldisserotto ${ }^{4}$
}

\begin{abstract}
The objective of this study was to evaluate the tolerance of piavas (Leporinus obtusidens) to ammonia $\left(\mathrm{NH}_{3}\right)$ by measuring its effects on plasma ion levels and tissue metabolic parameters. Piava juveniles (25-30 g) were exposed to five concentrations of $\mathrm{NH}_{3}\left(\mathrm{mg} \mathrm{L}^{-1}\right): 0.003$ (control), 0.1, 0.4, 0.7, and 1.4; after 96 hours, plasma levels of $\mathrm{Na}^{+}, \mathrm{K}^{+}, \mathrm{Cl}^{-}$and $\mathrm{NH}_{4}^{+}$ions and metabolic and enzyme activity in tissues (liver, kidneys, gills and muscle) were measured. The lethal concentration (LC50; 96h) of $\mathrm{NH}_{3}$ was 0.27 $\mathrm{mg} \mathrm{L}{ }^{-1}$. As $\mathrm{NH}_{3}$ increased, $\mathrm{Na}^{+}$and $\mathrm{NH}_{4}^{+}$in the plasma increased and $\mathrm{K}^{+}$decreased. In addition, $\mathrm{Na}^{+} / \mathrm{K}^{+}-$ ATPase activity concomitantly increased in the gills and decreased in the kidneys. Glucose, glycogen, and protein levels decreased, while lactate and ammonia increased in the tissues of piava juveniles that were treated with higher concentrations of ammonia. The observed lethal toxicity could be due to a gradual depletion of plasma ion levels and a reduction of metabolic and $\mathrm{Na}^{+} / \mathrm{K}^{+}$-ATPase activity in tissues. Both can lead to dysfunction in ionoregulatory and physiological systems. This finding has implications for the management of fish culture of piavas.
\end{abstract}

Key words: Ionoregulatory, lethal concentration, $\mathrm{Na}^{+} / \mathrm{K}^{+}$-ATPase

\section{Resumo}

O objetivo deste trabalho foi avaliar a tolerância de piava (Leporinus obtusidens) a diferentes concentrações de amônia da água e os efeitos sobre seus íons plasmáticos e parâmetros metabólicos. Juvenis de piava (25-30 g) foram expostos a diferentes concentrações de amônia da água $\left(\mathrm{mg} / \mathrm{L} \mathrm{NH}_{3}\right): 0,003$ (controle); 0,$1 ; 0,4 ; 0,7$ e 1,4, por 96 horas. Foram analisados níveis de $\mathrm{Na}^{+}, \mathrm{K}^{+}, \mathrm{Cl}^{-e} \mathrm{NH}_{4}^{+}$no plasma e metabolismo e atividade enzimática nos tecidos (fígado, rim, brânquias e músculo). A concentração letal (LC50; 96h) foi de $0,27 \mathrm{mg} / \mathrm{L}$ de $\mathrm{NH}_{3}$, e os níveis plasmáticos de $\mathrm{Na}^{+}$e $\mathrm{NH}_{4}{ }^{+}$aumentaram, enquanto os níveis de $\mathrm{K}^{+}$diminuíram com o aumento das concentrações de $\mathrm{NH}_{3}$ na água. A atividade de $\mathrm{Na}^{+} / \mathrm{K}^{+}$-ATPase aumentou nas brânquias e diminuiu nos rins com o aumento das concentrações de $\mathrm{NH}_{3}$ na água. Níveis de glicose, glicogênio e proteína (exceto no músculo) também reduziram, mas níveis de lactato aumentaram nos tecidos dos juvenis expostos as maiores concentrações de $\mathrm{NH}_{3}$ na água. A toxicidade letal observada poderia ser devido a depleção gradual de íons no plasma, a redução do metabolismo e a atividade nos tecidos de $\mathrm{Na}^{+} / \mathrm{K}^{+}$-ATPase. $\mathrm{O}$ aumento das concentrações de amônia na água leva ao acúmulo de amônia no plasma e nos tecidos, o que reduz o gradiente de difusão plasma-água de $\mathrm{NH}_{3}$ e induz alterações metabólicas e ionoregulatórias nas piavas, o que tem implicações para o manejo de piavas.

Palavras-chave: Ionoregulação, concentração letal, $\mathrm{Na}^{+}, \mathrm{K}^{+}$-ATPase, manejo

\footnotetext{
1 Prof., Dept ${ }^{\circ}$ de Zoologia, Universidade Federal da Bahia, UFBA, Salvador, BA, Brasil. E-mail: carloseduardocopatti@yahoo. com.br

2 Discentes, Dept ${ }^{\mathrm{o}}$ de Fisiologia e Farmacologia, Universidade Federal de Santa Maria, UFSM, Santa Maria, RS, Brasil. E-mail: kcsbolner@gmail.com; flrosso@gmail.com

3 Prof ${ }^{a}$, Dept $^{\circ}$ de Química, UFSM, Santa Maria, RS, Brasil. E-mail: vania.loro@gmail.com

4 Prof., Dept ${ }^{\text {o }}$ de Fisiologia e Farmacologia, UFSM, Santa Maria, RS, Brasil. E-mail: bbaldisserotto@hotmail.com

* Author for correspondence
} 


\section{Introduction}

Teleost fish are primarily ammoniotelic, and ammonia is the principal end-product of protein catabolism in most fish species. High ammonia concentrations may occur in intensive fish culture and can become unsafe unless ammonia is removed continuously either by biological filtration or periodical water change (HEGAZI et al., 2010). The toxicity of ammonia increases with water $\mathrm{pH}$ because its unionized form $\left(\mathrm{NH}_{3}\right)$ can diffuse across the gill membranes via the $\mathrm{Rh}$ glycoproteins (WRIGHT; WOOD, 2012), which then increases the proportion of $\mathrm{NH}_{3}$ in the water and subsequently decreases the diffusion gradient (ERDOGAN et al., 2005).

Ammonia is toxic to fishes and can cause convulsions, coma, and death. These consequences most likely occur because the elevated levels of $\mathrm{NH}_{4}^{+}$displace $\mathrm{K}^{+}$, which increases neuronal firing rate (ERDOGAN et al., 2005; WALSH et al., 2007). Chronic or sublethal exposure to $\mathrm{NH}_{3}$ can also cause degeneration of tissues in the gills (MIRON et al., 2008). Sub-lethal ammonia concentrations decrease the growth rate of fish (MIRON et al., 2011; FERREIRA et al., 2013), interfering in the artificial fertilization (VIDAL et al., 2013) and may cause several physiological and histological changes (WRIGHT; WOOD, 2012; LIEW et al., 2013). For these reasons, toxicity of ammonia to fish has been intensively investigated in numerous fish species (BENLÍ; KÖKSAL, 2005; ERDOGAN et al., 2005; MIRON et al., 2008; LIEW et al., 2013; FERREIRA et al., 2013).

Tolerance to high environmental ammonia concentrations varies among freshwater species (MIRON et al., 2008; LIEW et al., 2013). Species such as Opsanus beta, Opsanus tau, and Porichthys notatus are known to tolerate high concentrations of ammonia in the water (WANG; WALSH, 2000). Such highly tolerant species may have evolved specialized strategies that may reduce the toxicity of ammonia through physiological alterations
(RANDALL; TSUI, 2002). For example, some species produce derived compounds, such as urea in Clarias batrachus (SAHA et al., 2002) and glutamine in Oncorhynchus mykiss (rainbow trout) (WICKS; RANDALL, 2002). Therefore, tolerance concentrations should be determined according to species-specific thresholds (SCHRAM et al., 2010).

Piava, Leporinus obtusidens Valenciennes (1847), can be found in Brazil, mainly in the São Francisco, Paraná and the Uruguai Basins and is an important native species for fish culture in South Brazil (COPATTI; AMARAL, 2009; REYNALTETATAJE; ZANIBONI-FILHO, 2010) that adapts well to different stocking density and feeding frequency (COPATTI et al., 2008). No study has analyzed the tolerance of piavas to the acute exposure to ammonia and the effects on their ionoregulatory and metabolic parameters. The objective of this work was to provide this information.

\section{Materials and Methods}

Piava juveniles (8-11 cm; 26-29 g) were purchased from a local fish culture, transported to the Fish Physiology Laboratory at the Universidade Federal de Santa Maria, and kept in continuously aerated $250 \mathrm{~L}$ tanks $\left(23^{\circ} \mathrm{C}, \mathrm{pH} 7.4\right.$, water hardness 30 $\left.\mathrm{mg} \mathrm{L}^{-1} \mathrm{CaCO}_{3}\right)$ for two weeks. After acclimation (10 days), the fish were then transferred randomly into continuously aerated $40 \mathrm{~L}$ tanks (10 juveniles per tank) with the following $\mathrm{NH}_{3}$ concentrations: 0.003 (control), $0.1 \pm 0.06,0.4 \pm 0.11,0.7 \pm 0.13$, and $1.4 \pm$ $0.19 \mathrm{mg} \mathrm{L}^{-1}$ (in triplicate). The concentrations were chosen according to previous studies of Serafini et al. (2009) for dourado (Salminus brasiliensis) and Ferreira et al. (2013) for silver catfish (Rhamdia quelen). The fish were first kept in their respective tanks for $96 \mathrm{~h}$, and then $\mathrm{NH}_{4} \mathrm{Cl}$ was added to increase $\mathrm{NH}_{3}$ to experimental concentrations.

The tanks were siphoned daily to remove residues and feces, and at least $20-40 \%$ of the water was replaced with water that had been adjusted according to the experimental $\mathrm{NH}_{3}$ level. The fish 
were not fed during the experiment, the tanks were checked for dead fish every two hours, and the number of dead fish was recorded.

For all individuals, tissues from the liver, kidneys, muscle, and gills were collected at the end of the experiment or when fish showed complete equilibrium loss and very low opercular movements (which tended to occur at the higher $\mathrm{NH}_{3}$ concentrations). Specimens were stored in liquid nitrogen until analyses. Tissue samples were homogenized in $100 \mathrm{mg} \mathrm{L}^{-1} 20 \%$ trichloride acetic acid using a Potter-Elvehjem type homogenizer (1000 rpm per $3 \mathrm{~min}$ in ice bath) and then centrifuged at $3000 \mathrm{x} \mathrm{g}$ for $5 \mathrm{~min}$. The supernatants were used to determine the concentrations of ammonia (VERDOUW et al., 1978), glucose, glycogen (DUBOIS et al., 1956), lactate (HARROWER; BROWN, 1972), and protein (LOWRY et al., 1951) in the liver, kidneys and muscle tissues.

To assay $\mathrm{Na}^{+} / \mathrm{K}^{+}$-ATPase in gills and kidneys, the tissue samples were homogenized with a PotterElvehjem type homogenizer with a 1:5 ratio of SET (sacarose-EDTA-TRIS; pH 7.5) buffer. Next, the homogenate was centrifuged for $5 \mathrm{~min}$ at $6000 \mathrm{x}$ $\mathrm{g}$, and the supernatant was used for enzyme assays adaptated from (FLIK et al., 1983). Blood was collected from the caudal vein with heparinized 1 $\mathrm{mL}$ syringes and centrifuged at $1200 \mathrm{xg}$ for $5 \mathrm{~min}$ to separate the plasma. The $\mathrm{Na}^{+}$and $\mathrm{K}^{+}$levels were analyzed with a B262 flame spectrophotometer (Micronal, São Paulo, Brazil); the $\mathrm{Cl}^{-}$levels were determined according to the protocol described by Zall et al. (1956).

The water quality parameters were kept constant to avoid variation in $\mathrm{NH}_{3}$ toxicity. The dissolved oxygen levels and temperature were measured every two hours using an YSI oxygen meter (model Y5512, Yellow Springs, USA), and temperature was maintained at $25{ }^{\circ} \mathrm{C}$ using an air conditioner in the laboratory. Water $\mathrm{pH}$ was monitored with a BNC Oakton pH meter (model 400A) and sustained within a neutral range (7.0-7.2). Water samples were collected every two hours and frozen for analysis of the total ammonia as described by Verdouw et al. (1978); $\mathrm{NH}_{3}$ concentrations were calculated according to Colt (2002). Water hardness and alkalinity were determined using the EDTA titrimetric method (EATON et al., 2005). At the time of water sample collection, the behavior of the fish (e.g., swimming and equilibrium) was observed.

The data are reported as the mean \pm SEM and $95 \%$ confidence intervals. Homogeneity of variances among the groups was determined with a Levene test. The data showed homogeneous variances. The lethal concentration of $\mathrm{NH}_{3}$ at $96 \mathrm{~h}(\mathrm{LC} 50 ; 96 \mathrm{~h})$ was calculated by the probit method (FINNEY, 1971), an analysis which has been widely used for many years to calculate LC50. The relationships between $\mathrm{NH}_{3}$ concentrations and metabolic parameters were examined using Sigma Plot 8.0 software. If no significant relationship was found, comparisons between treatments were performed with one-way analysis of variance and Tukey test using Statistica software (version 7) $(\mathrm{P}<0.05)$.

\section{Results}

Only the control $\left(0.03 \mathrm{mg} \mathrm{L}^{-1}\right)$ and $0.1 \mathrm{mg} \mathrm{L}^{-1}$ $\mathrm{NH}_{3}$ treatment groups exhibited $100 \%$ survival. The exposure of piava to $\mathrm{NH}_{3}$ concentrations of $0.4 \mathrm{mg}$ $\mathrm{L}^{-1}$ or higher caused altered locomotive behavior and then death. Mortality was 78\%, 100\% (after 72 h), and $100 \%$ (after $48 \mathrm{~h}$ ) at $0.4,0.7$, and $1.4 \mathrm{mg} \mathrm{L}^{-1}$ $\mathrm{NH}_{3}$, respectively. The $\mathrm{LC}_{50-96 \mathrm{~h}}$ of $\mathrm{NH}_{3}$ for piava is $0.27 \mathrm{mg} \mathrm{L}^{-1}$ (confidence interval: $0.21-0.34 \mathrm{mg} \mathrm{L}^{-1}$ ). Plasma levels of $\mathrm{Na}^{+}$and $\mathrm{NH}_{4}^{+}$increased with $\mathrm{NH}_{3}$, whereas levels of $\mathrm{K}^{+}$decreased and $\mathrm{Cl}^{-}$remained stable (Figure 1).

Total $\mathrm{NH}_{3}$ increased in the liver, kidneys, and muscle and $\mathrm{Na}^{+} / \mathrm{K}^{+}$-ATPase activity increased in the gills and decreased in the kidneys (Figures 2 and 3). The lactate levels in the liver, kidneys, and muscle increased with the $\mathrm{NH}_{3}$ concentrations (Figure 4). In contrast, glucose, glycogen, and protein decreased in the liver and kidneys, and glucose and glycogen decreased in muscle (Figures 5, 6 and 7). 
Figure 1. Ion and $\mathrm{NH}_{4}^{+}$plasma levels in piava (y) as a function of $\mathrm{NH}_{3}$ concentrations (x). The following equations were fitted to the data: $\mathrm{A}=\mathrm{Na}^{+}: \mathrm{r}^{2}=0.92, \mathrm{y}=84.17+139.14 \mathrm{x} ; \mathrm{B}=\mathrm{Cl}-$ : no relationship or significant difference; $\mathrm{C}=\mathrm{K}^{+}$: $\mathrm{r}^{2}=0.97, \mathrm{y}=8.02-3.82 \mathrm{x} ; \mathrm{D}=\mathrm{NH}_{4}^{+}=\mathrm{r}^{2}=0.94, \mathrm{y}=8.31+14.08 \mathrm{x}$.
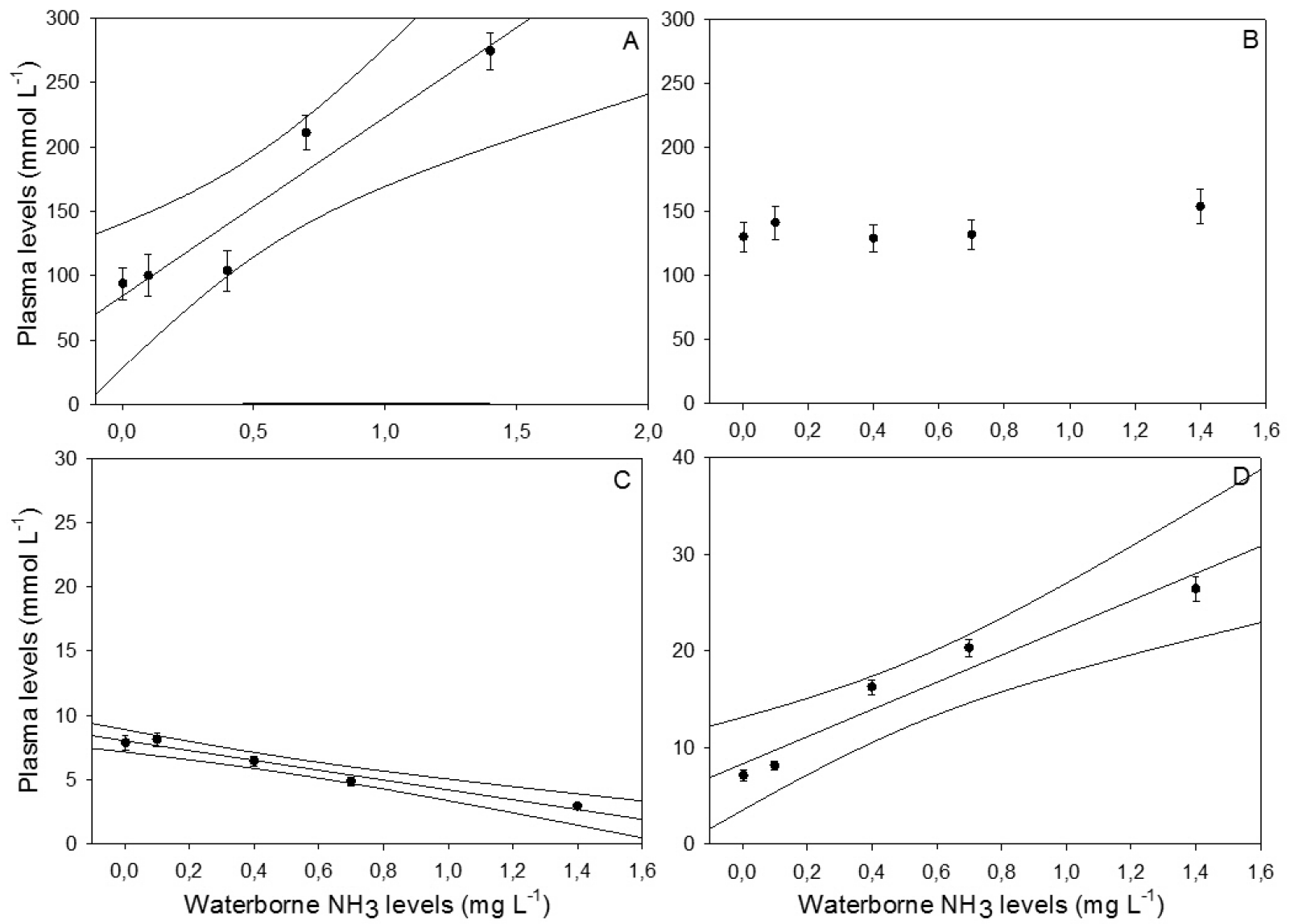
Figure 2. Ammonia levels in the tissues of piava (y) as a function of $\mathrm{NH}_{3}$ concentrations (x). The following equations were fitted to the data: $\mathrm{A}=$ liver: $\mathrm{r}^{2}=0.89, \mathrm{y}=89.12+165.01 \mathrm{x} ; \mathrm{B}=$ kidneys: $\mathrm{r}^{2}=0.96, \mathrm{y}=57.24+84.98 \mathrm{x} ; \mathrm{C}=$ muscle: $\mathrm{r}^{2}=0.95, \mathrm{y}=104.58+194.23 \mathrm{x}$.
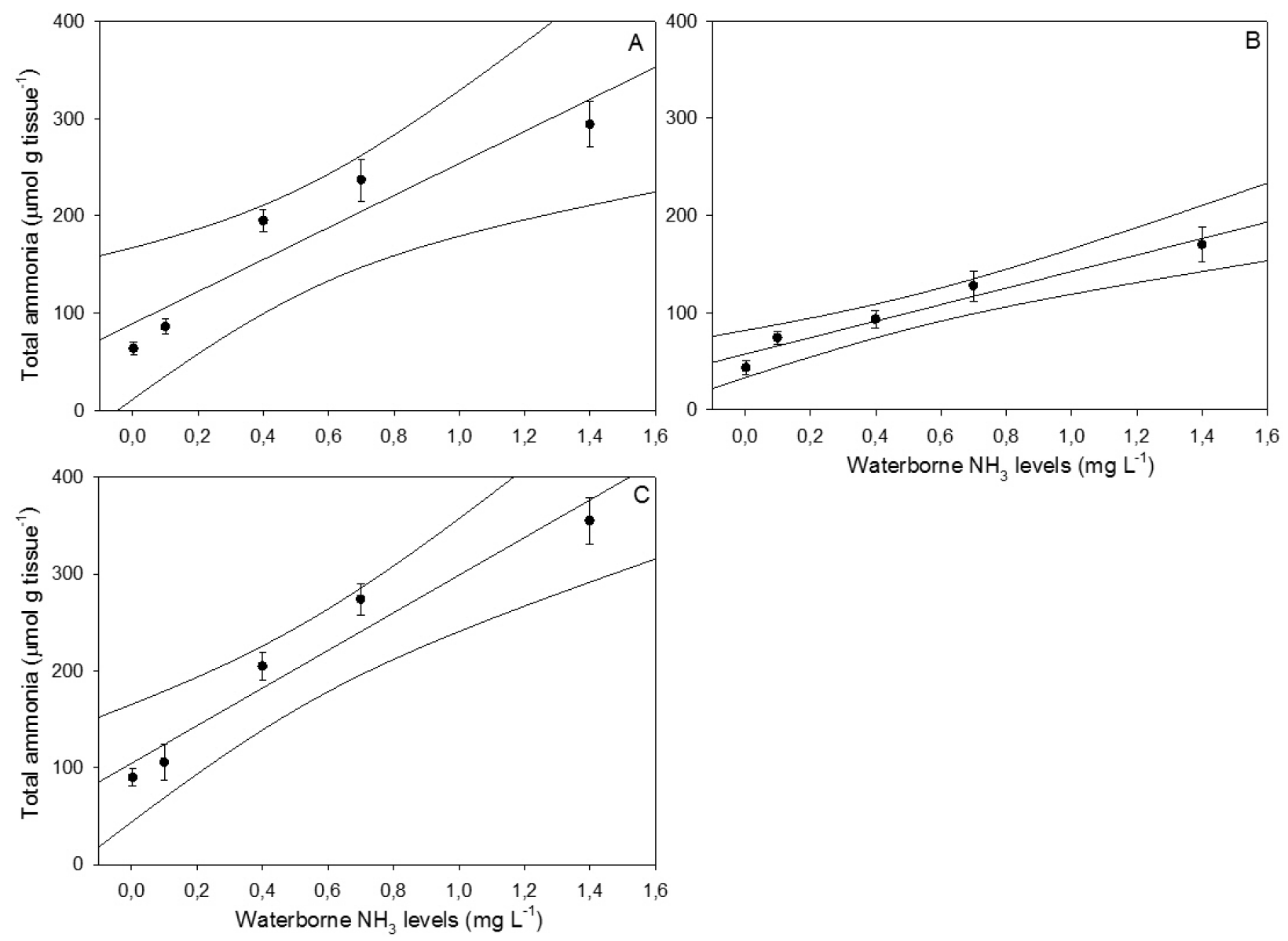

Figure 3. $\mathrm{Na}^{+} / \mathrm{K}^{+}$-ATPase activity in the gills and kidneys of piava (y) as a function of $\mathrm{NH}_{3}$ concentrations (x). The following equations were fitted to the data: $\mathrm{A}=$ gills: $\mathrm{r}^{2}=0.93, \mathrm{y}=14.38+42.13 \mathrm{x} ; \mathrm{B}=$ kidneys: $\mathrm{r}^{2}=0.88, \mathrm{y}=31.68-$ $18.10 \mathrm{x}$.
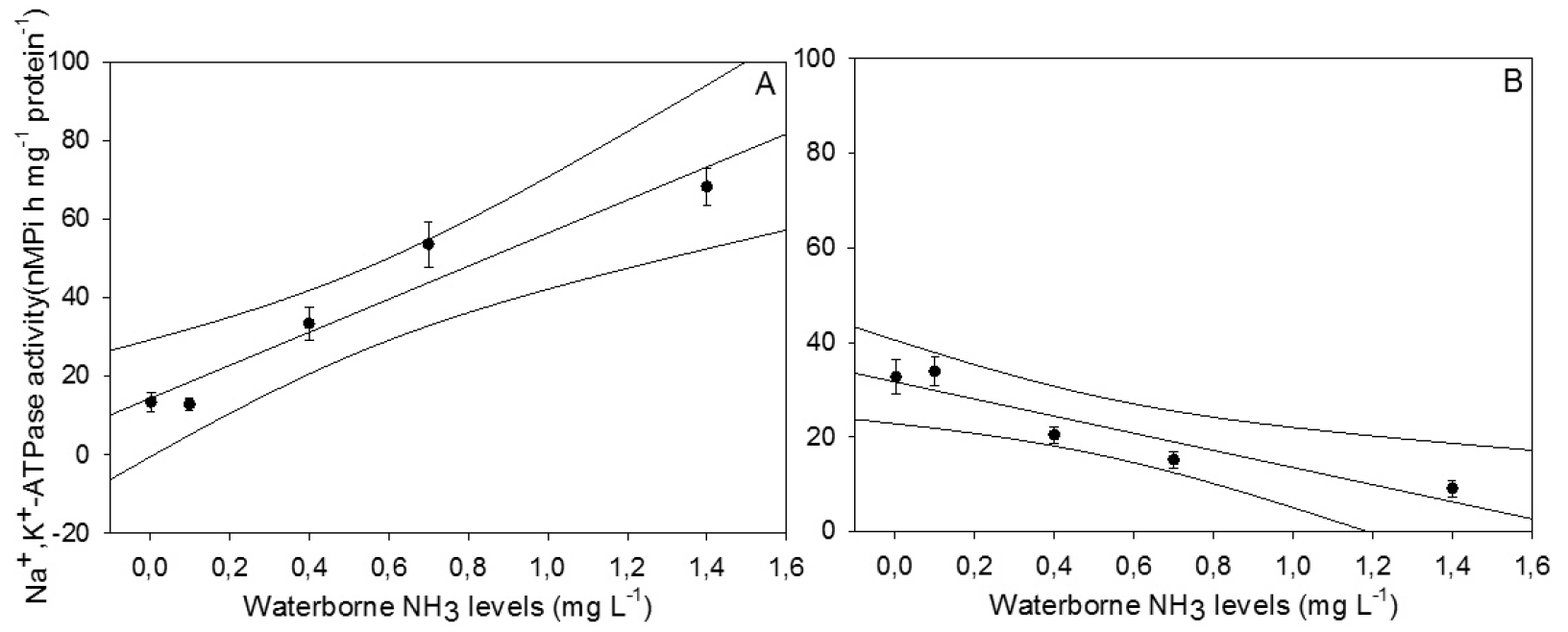
Figure 4. Lactate levels in the tissues of piava (y) as a function of $\mathrm{NH}_{3}$ concentrations (x). The following equations were fitted to the data: $\mathrm{A}=$ liver: $\mathrm{r}^{2}=0.97, \mathrm{y}=86.41+72.13 \mathrm{x} ; \mathrm{B}=$ kidneys: $\mathrm{r}^{2}=0.87, \mathrm{y}=74.35+57.82 \mathrm{x} ; \mathrm{C}=$ muscle: $\mathrm{r}^{2}=0.93, \mathrm{y}=1382.24+1133.93 \mathrm{x}$.
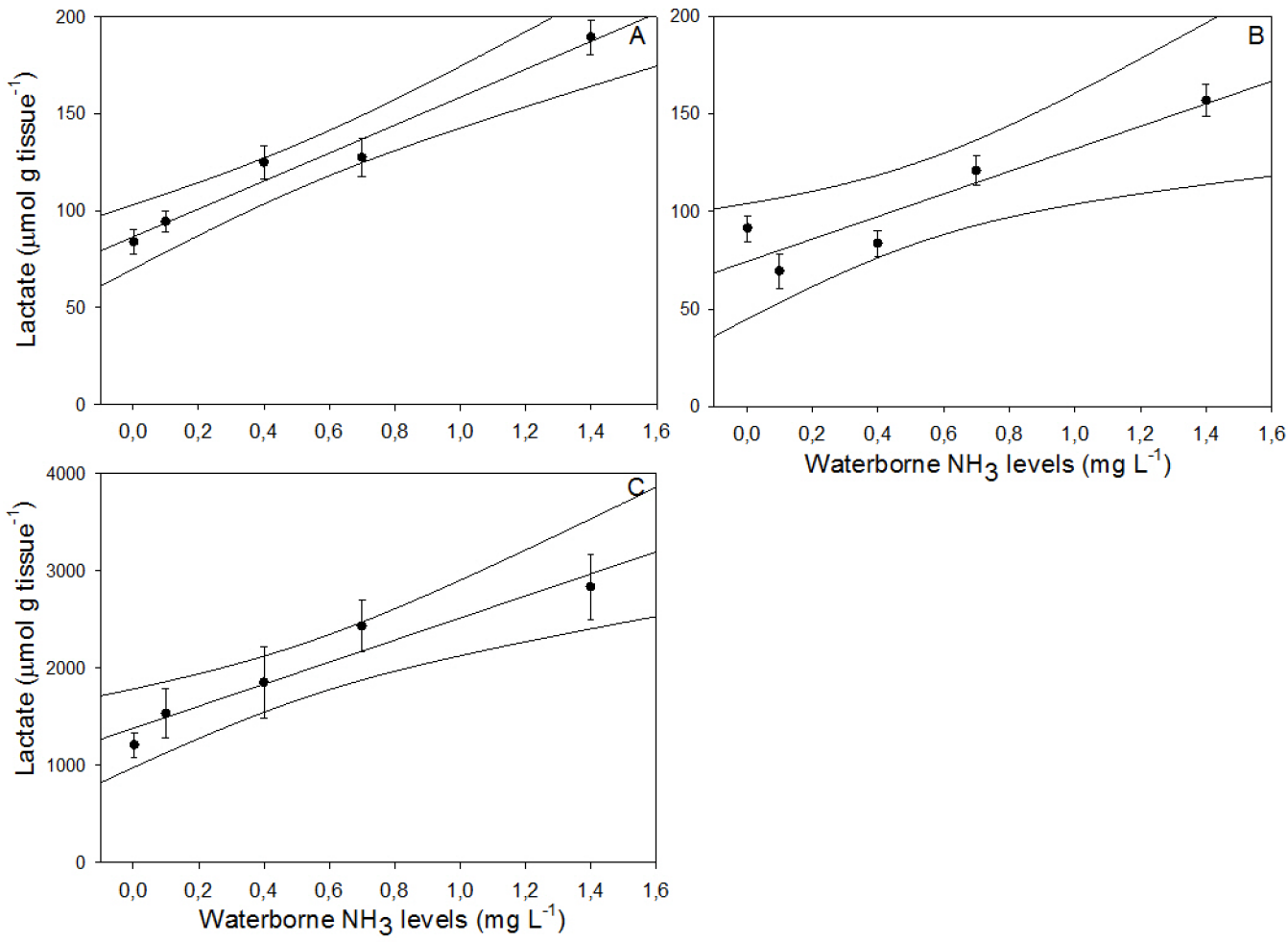

Figure 5. Glucose levels in the tissues of piava (y) as a function of $\mathrm{NH}_{3}$ concentrations (x). The following equations were fitted to the data: $\mathrm{A}=$ liver: $\mathrm{r}^{2}=0.91, \mathrm{y}=43.11-22.49 \mathrm{x} ; \mathrm{B}=$ kidneys: $\mathrm{r}^{2}=0.85, \mathrm{y}=12.37-7.09 \mathrm{x} ; \mathrm{C}=$ muscle: $\mathrm{r}^{2}=$ $0.89, \mathrm{y}=65.94-43.50 \mathrm{x}$.
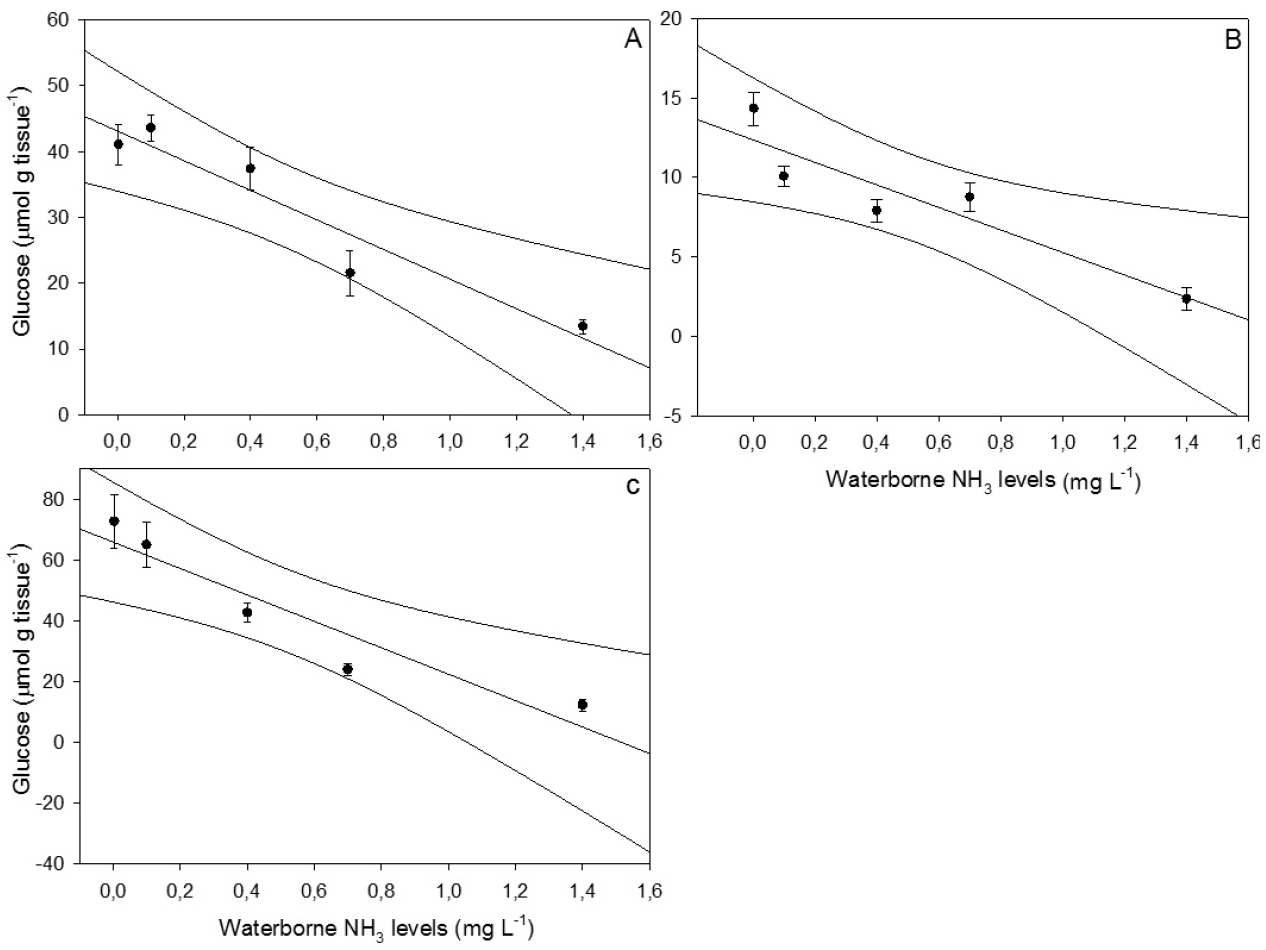
Figure 6. Glycogen levels in the tissues of piava (y) as a function of $\mathrm{NH}_{3}$ concentrations (x). The following equations were fitted to the data: $\mathrm{A}=$ liver: $\mathrm{r}^{2}=0.97, \mathrm{y}=109.19-41.85 \mathrm{x} ; \mathrm{B}=$ kidneys: $\mathrm{r}^{2}=0.93, \mathrm{y}=71.49-31.30 \mathrm{x} ; \mathrm{C}=$ muscle: $r^{2}=0.86, y=128.67-69.58$.
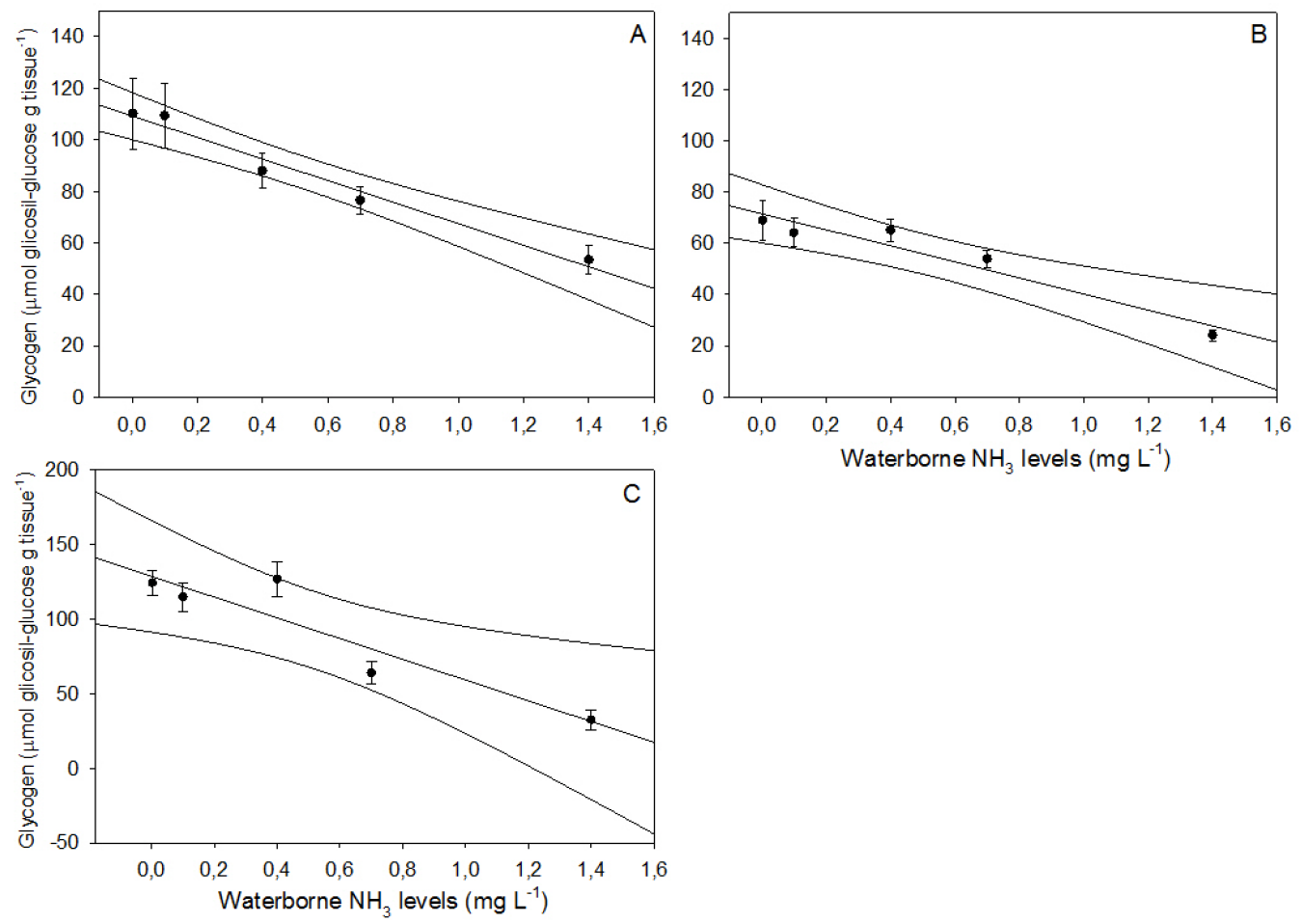

Figure 7. Protein levels in the tissues of piava (y) as a function of $\mathrm{NH}_{3}$ concentrations (x). The following equations were fitted to the data: $\mathrm{A}=$ liver: $\mathrm{r}^{2}=0.98, \mathrm{y}=80.48-33.49 \mathrm{x} ; \mathrm{B}=$ kidneys: $\mathrm{r}^{2}=0.90, \mathrm{y}=51.19-29.34 \mathrm{x} ; \mathrm{C}=$ muscle: no relationship or significant difference.
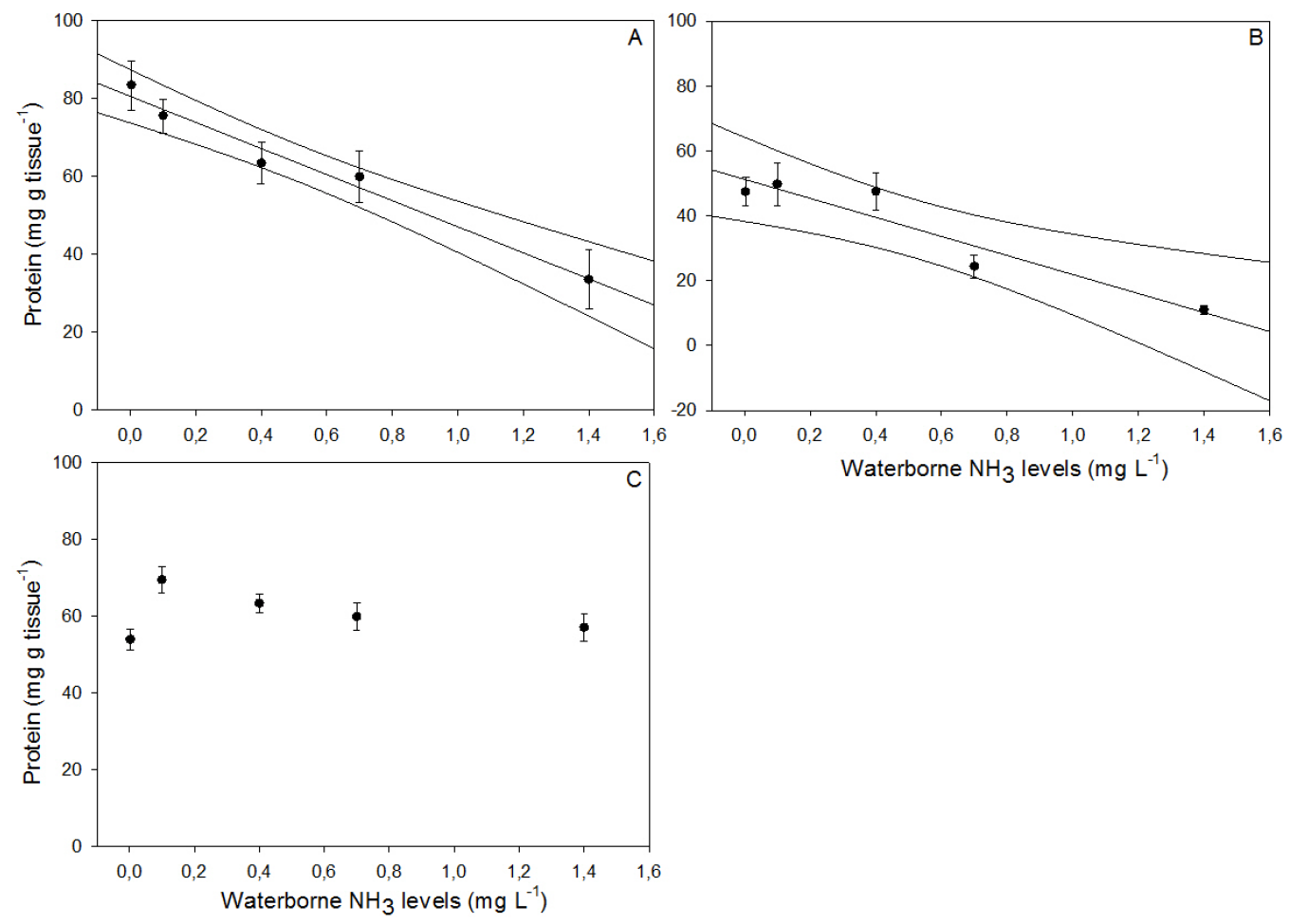


\section{Discussion}

In this experiment, piavas that were exposed to the higher concentrations of $\mathrm{NH}_{3}$ demonstrated responses that are typical of fish that are under short-term exposure to ammonia, including loss of equilibrium, erratic swimming, and death (RANDALL; TSUI, 2002; WALSH et al., 2007). The observed behaviors are consistent with previous descriptions of the damaging effects on the central nervous system that may be caused by acute $\mathrm{NH}_{3}$ toxicity (RANDALL; TSUI, 2002; WALSH et al., 2007). Exposure to sub-lethal concentrations of $\mathrm{NH}_{3}$ halts the metabolism of amino acids and mitochondria in the brain (WALSH et al., 2007). Similar results were described for sea bass (Dicentrarchus labrax), sea bream (Sparus aurata), and turbot (Scophthalmus maximus) juveniles that were exposed to $6.43,4.87$ and $5.70 \mathrm{mg} \mathrm{L}^{-1} \mathrm{NH}_{3}$, respectively, for $96 \mathrm{~h}$ (RUYET et al., 1995), although these species could adopt a different physiological pattern of the species of this study, because they are adapted to colder waters.

The $\mathrm{LC}_{50-96 \mathrm{~h}}$ of $\mathrm{NH}_{3}$ for piava is $0.27 \mathrm{mg} \mathrm{L}^{-1}$, which suggests that this species is less resistant to $\mathrm{NH}_{3}$ toxicity than some other freshwater species. For example, the $\mathrm{LC}_{50-96 \mathrm{~h}}$ of $\mathrm{NH}_{3}$ is between 1.20$1.45 \mathrm{mg} \mathrm{L}^{-1}$ for silver catfish (MIRON et al., 2008, FERREIRA et al., 2013), $1.83 \mathrm{mg} \mathrm{L}^{-1}$ for dourado (SERAFINI et al., 2009), and $7.40 \mathrm{mg} \mathrm{L}^{-1}$ for Nile tilapia (Oreochromis niloticus) (BENLÍ; KÖKSAl, 2005). African catfish (Clarias gariepinus) that are chronically exposed to $\mathrm{NH}_{3}$ concentrations as high as $3.04 \mathrm{mg} \mathrm{L}^{-1}$ did not show any major physiological disruptions, except some effects on gill morphology. When ammonia exceeds the tolerance concentration it causes acute or chronic stress, leading to mortality (PERSON-LE RUYET et al., 1997). The same was observed in the present study with piava. Therefore, for this species, it is advised that $\mathrm{NH}_{3}$ concentrations do not exceed $0.41 \mathrm{mg} \mathrm{L}^{-1}$ to minimize the risk of reduced growth and consumption (SCHRAM et al., 2010).
The low resistance of piava to ammonia toxicity explains the physiological changes described in this study. In this study, plasma ammonia levels were expected to increase with $\mathrm{NH}_{3}$ concentration because higher $\mathrm{NH}_{3}$ concentrations would decrease the plasma-water gradient for $\mathrm{NH}_{3}$ diffusion. As a consequence, $\mathrm{NH}_{3}$ excretion would decrease. Seabass, seabream, and turbot juveniles that were exposed to $6.43,4.87$, and $5.70 \mathrm{mg} \mathrm{L}^{-1} \mathrm{NH}_{3}$, respectively, for $96 \mathrm{~h}$ also exhibited increased plasma concentrations of $\mathrm{NH}_{3}$ (RUYET et al., 1995). Seabass that were exposed to different $\mathrm{NH}_{3}$ concentrations $\left(0.71,0.88\right.$ and $\left.0.90 \mathrm{mg} \mathrm{L}^{-1}\right)$ for 63 days showed a positive relationship between plasma ammonia and $\mathrm{NH}_{3}$ concentrations (LEMARIÉ et al., 2004). The high $\mathrm{NH}_{3}$ concentrations may have also affected ammonia levels of other tissues (Fig. 2).

After exposure to $0.11 \mathrm{mg} \mathrm{L}^{-1} \mathrm{NH}_{3}$ for $12 \mathrm{~h}$ and up to seven days, $\mathrm{Na}^{+}$uptake increased in rainbow trout, goldfish (Carassius auratus), and carp (Cyprinus carpio), possibly due to the activation of the branchial apical " $\mathrm{Na}^{+} / \mathrm{NH}_{4}^{+}$exchange metabolon" (LIEW et al., 2013). It is likely that this mechanism was also activated in the piava with the replacement of $\mathrm{NH}_{4}^{+}$by $\mathrm{K}^{+}$in the basolateral $\mathrm{Na}^{+}$/ $\mathrm{K}^{+}$-ATPase, which led to an increase in $\mathrm{Na}^{+}$and a decrease in $\mathrm{K}^{+}$plasma levels.

Liew et al. (2013) observed that diffusive water efflux rates and net $\mathrm{K}^{+}$loss rates across the gills were enhanced during exposure to $0.11 \mathrm{mg} \mathrm{L}^{-1}$ $\mathrm{NH}_{3}$ in rainbow trout, which indicates increased gill transcellular permeability. The net $\mathrm{K}^{+}$loss rates across the gills must have occurred in this study, since plasma levels of $\mathrm{K}$ decreased at the highest $\mathrm{NH}_{3}$ concentrations. On the other hand, silver catfish exposed to $0.1 \mathrm{mg} \mathrm{L}^{-1} \mathrm{NH}_{3}$ for $6-24 \mathrm{~h}$ had higher plasma $\mathrm{Na}^{+}, \mathrm{K}^{+}$and $\mathrm{Cl}^{-}$levels compared to those exposed to $0.03 \mathrm{mg} \mathrm{L}^{-1} \mathrm{NH}_{3}$ (BECKER et al., 2009). The effects of $\mathrm{NH}_{3}$ on plasma ion levels of freshwater fish seem to be highly species-dependent and vary according to the $\mathrm{pH}$ and $\mathrm{NH}_{3}$ concentration of the water (BOLNER et al., 2014). 
At high $\mathrm{NH}_{3}$ concentrations, $\mathrm{Na}^{+} / \mathrm{K}^{+}$-ATPase activity increased in the gills but decreased in the kidneys of piavas. This finding was expected because upregulation of the " $\mathrm{Na}^{+} / \mathrm{NH}_{4}^{+}$exchange metabolon" in the gills is often associated with increased gene expression and/or enzyme activity of $\mathrm{Na}^{+} / \mathrm{K}^{+}$-ATPase (WRIGHT; WOOD, 2012) in order to efficiently eliminate the excess ammonia. Silver perch (Bidyanus bidyanus) and gold perch (Macquaria ambigua) exposed to $5 \mathrm{mg} \mathrm{L}^{-1} \mathrm{NH}_{3}$ for $120 \mathrm{~h}$ also displayed increased $\mathrm{Na}^{+} / \mathrm{K}^{+}$-ATPase activity in the gills (ALAM; FRANKEL, 2006). In freshwater fish, kidneys produce a very dilute urine (BOLNER; BALDISSEROTTO, 2007), and the reduction in $\mathrm{Na}^{+} / \mathrm{K}^{+}$-ATPase activity at high $\mathrm{NH}_{3}$ concentrations suggests a deficiency in tubular ion reabsorption.

Stressed fish are expected to increase plasma glucose and decrease glycogen levels to contribute to the increase in energy demand (BARCELLOS et al., 2004). However, piava exposed to high $\mathrm{NH}_{3}$ concentrations (>0.4 $\mathrm{mg} \mathrm{L}^{-1)}$, had permanent stress, demonstrated by the higher mortality rates and lower glucose, glycogen and protein levels than control group and $0.1 \mathrm{mg} \mathrm{L}^{-1} \mathrm{NH}_{3}$ treatment after $96 \mathrm{~h}$. Silver catfish exposed to $0.50 \mathrm{mg} \mathrm{L}^{-1} \mathrm{NH}_{3}$ increased significantly plasma glucose in the first $24 \mathrm{~h}$, but presetned $100 \%$ mortality within 5 days (BALDISSEROTTO et al., 2014).

So, the reduction in glucose and glycogen in the tissues can be explained by the use of these substrates in the energetic demand required for $\mathrm{NH}_{3}$ excretion. The stress of the exposure to high $\mathrm{NH}_{3}$ concentrations results in an increase of plasma cortisol levels in fish (LIEW et al., 2013), which stimulates glycogenolysis and gluconeogenesis and increases protein catabolism (RANDALL; TSUI, 2002), possibly due to catecholaminemediated glycogenolysis and cortisol-mediated gluconeogenesis (PANKHURST, 2011). This process likely occurred in piava that were exposed to high $\mathrm{NH}_{3}$ concentrations, resulting in lower protein levels in the tissues due to the catabolic process. The metabolism of piava juveniles could be an adaptation that has evolved in response to the energetic demands of $\mathrm{NH}_{3}$ excretion.

Lactate is a final product of anaerobic glycolysis during intense exercise or stress, due to poor muscle oxygenation or alteration of the aerobic respiration (WENDELAAR BONGA, 1997). In the present study, the increase in lactate in the tissues suggests that the increase in $\mathrm{NH}_{3}$ concentrations caused the piava to employ an anaerobic route with the use of lactate as substrate for gluconeogenesis. On the other hand, Baldisserotto et al. (2014) did not show alterations in plasma lactate levels in silver catfish exposed to 0.18 or $0.50 \mathrm{mg} \mathrm{L}^{-1} \mathrm{NH}_{3}$ on the first $24 \mathrm{~h}$ of experiment.

The results suggest that the observed lethal toxicity $\left(0.27 \mathrm{mg} \mathrm{L}^{-1} \mathrm{NH}_{3}\right)$ could be related to a gradual disruption of ionic levels in the plasma and metabolic and $\mathrm{Na}^{+} / \mathrm{K}^{+}$-ATPase activity in tissues, both of which could then lead to the depression of physiological and ionoregulatory systems. Treatment with the highest concentrations of $\mathrm{NH}_{3}$ (>0.4 $\mathrm{mg} \mathrm{L}^{-1)}$ showed higher plasma levels of lactate and the lower glucose and glycogen levels. $\mathrm{NH}_{3}$ is a stressor for piava, and its effect is immediate but concentration dependent. The results are helpful to fish culture farmers in preventing the decreased productivity that may be caused by elevated $\mathrm{NH}_{3}$ concentrations (>0.1 $\left.\mathrm{mg} \mathrm{L}^{-1} \mathrm{NH}_{3}\right)$.

\section{Acknowledgements}

The authors thank CNPq (Conselho Nacional de Desenvolvimento Tecnológico, Brazil) for their financial support and research fellowships to V.L.L. and B.B.

\section{References}

ALAM, M.; FRANKEL, T. L. Gill ATPase activities of silver perch, Bidyanus bidyanus (Mitchell), and golden perch, Macquaria ambigua (Richardson): effects of environmental salt and ammonia. Aquaculture, New York, v. 251, n. 1, p. 118-133, 2006. 
BALDISSEROTTO, B.; MARTOS-SITCHA, J. A.; MENEZES, C. C.; TONI, C.; PRATI, R. L.; GARCIA, L. de O.; SALBEGO, J.; MANCERA, J. M.; MARTÍNEZRODRÍGUEZ, G. The effects of ammonia and water hardness on the hormonal, osmoregulatory and metabolic responses of the freshwater silver catfish Rhamdia quelen. Aquatic Toxicology, New York, v. 152, n. 1, p. 341-352, 2014.

BARCELlOS, L. J.; KREUTZ, L. C.; SOUZA, C. D.; RODRIGUESA, L. B.; FIOREZE, I.; QUEVEDO, R. M.; CERICATO, L.; SOSO, A. B.; FAGUNDES, M.; CONRAD, J.; LACERDA, L. A.; TERRA, S. Hematological changes in jundiá (Rhamdia quelen Quoy and Gaimard Pimelodidae) after acute and chronic stress caused by usual aquacultural management, with emphasis on immunosuppressive effects. Aquaculture, New York, v. 237, n. 1, p. 229-236, 2004.

BECKER, A. G.; GARCIA, L. O.; KOCHHANN, D.; GONÇALVES, J. F.; LORO, V. L.; BALDISSEROTTO, B. Dissolved oxygen and ammonia levels in water that affect plasma ionic content and gallbladder bile in silver catfish. Ciência Rural, Santa Maria, v. 39, n. 6, p. 17681773, 2009.

BENLÍ, A. C. K.; KÖKSAL, G. The acute toxicity of ammonia on tilapia (Oreochromis niloticus L.) larvae and fingerlings. Turkish Journal of Veterinary and Animal Sciences, Kırıkkale, v. 29, n. 2, p. 339-344, 2005.

BOLNER, K. C. S.; BALDISSEROTTO, B. Water pH and urinary excretion in silver catfish Rhamdia quelen. Journal of Fish Biology, v. 70, n. 1, p. 50-64, 2007.

BOLNER, K. C. S.; COPATTI, C. E.; ROSSO, F. L.; LORO, V. L.; BALDISSEROTTO, B. Water $\mathrm{pH}$ and metabolic parameters in silver catfish (Rhamdia quelen). Biochemical Systematics and Ecology, New York, v. 56, n. 1, p. 202-208, 2014.

COLT, J. List of spreadsheets prepared as a complement. In: WEDEMEYER, G. A. (Ed.). Fish hatchery management. $2^{\text {th }}$ ed. Bethesda: American Fisheries Society Publication, 2002. 751 p. Available at: <www. fisheries.org/afs/hatchery.html $>$. Accessed at: $14 \mathrm{dec}$. 2013.

COPATTI, C. E.; AMARAL, R. Osmorregulação em juvenis de piava, Leporinus obtusidens (Characiformes: Anastomidae), durante trocas do $\mathrm{pH}$ da água. Biodiversidade Pampeana, Uruguaiana, v. 7, n. 1, p. 1-6, 2009.

COPATTI, C. E.; DOS SANTOS, T. A.; GARCIA, S. F. S. Densidade de estocagem e frequência alimentar de juvenis de piava Leporinus obtusidens valenciennes, 1836 (Characiformes:Anostomidae). Revista Brasileira de Agrociências, Pelotas, v. 14, n. 4-4, p.1 07-111, 2008.
DUBOIS, M.; GILLES, K. A.; HAMILTON, J. K. Colorimetric method for determination of sugars and related substances. Analytical Chemistry, Washington, v. 28, n. 3, p. 350-358, 1956

EATON, A. D.; CLESCERI, L. S.; RICE, E. W.; GREENBERG, A. E. Standard methods for the examination of water and wastewater. $21^{\text {th }}$ ed. Washington: American Public Health Association, 2005. $1368 \mathrm{p}$.

ERDOGAN, O.; HISAR, O.; KOROGLU, G.; CILTAS, A. Sublethal ammonia and urea concentrations inhibit rainbow trout (Oncorhynchus mykiss) erythrocyte glucose-6-phosphate dehydrogenase. Comparative Biochemistry and Physiology C, New York, v. 141, n. 2, p. 145-150, 2005.

FERREIRA, F. W.; CUNHA, R. B.; BALDISSEROTTO, $B$. The survival and growth of juvenile silver catfish, Rhamdia quelen, exposed to different $\mathrm{NH}_{3}$ and hardness levels. Journal of the World Aquaculture Society, Hoboken, v. 44, n. 2, p. 293-299, 2013.

FINNEY, D. J. Probit analysis. Cambridge: Cambridge University Press, 1971. 333 p.

FLIK, G; WENDELAAR BONGA, S. E.; FENWICK, J. C. Ca -dependent phosphatase and ATPase activities in eel gill plasma membranes. I. Identification of $\mathrm{Ca}$ activated ATPase activities with non-specific phosphatase activities. Comparative Biochemistry and Physiology B, v. 76, n. 4, p.745-754, 1983.

HARROWER, J. R.; BROWN, C. H. Blood lactic acid. A micromethod adapted to field collection of microliter sample. Journal of Applied Physiology, Bethesda, v. 32, n. 5, p. 224-228, 1972.

HEGAZI, M. M.; ATTIA, Z. I.; ASHOUR, O. A. Oxidative stress and antioxidant enzymes in liver and white muscle of Nile tilapia juveniles in chronic ammonia exposure. Aquatic Toxicology, New York, v. 99, n. 1, p. 118-125, 2010.

LEMARIÉ, G.; DOSDAT, A.; COVES, D.; DUTTO, G.; GASSET, E.; RUYET, J. P. L. Effect of chronic ammonia exposure on growth of European seabass (Dicentrarchus labrax) juveniles. Aquaculture, New York, v. 229, n. 1, p. 479-491, 2004.

LIEW, H. J.; SINHA, A. K.; NAWATA, C. M.; BLUSTA, R.; WOOD, C. M.; DE BOECK, G. Differential responses in ammonia excretion, sodium fluxes and gill permeability explain different sensitivities to acute high environmental ammonia in three freshwater teleosts. Aquatic Toxicology, New York, v. 126, n. 1, p. 63-76, 2013. 
LOWRY, O. H.; ROSEBROUGH, N. J.; FARR, A. L.; RANDALL, R. J. Folin phenol reagent. Journal of Experimental Biology, Cambridge, v. 193, n. 1, p. 265275, 1951.

MIRON, D. S.; BECKER, A. G.; LORO, V. L.; BALDISSEROTTO, B. Waterborne ammonia and silver catfish, Rhamdia quelen: survival and growth. Ciência Rural, Santa Maria, v. 41, n. 2, p. 49-353, 2011.

MIRON, D. S.; MORAES, B.; BECKER, A. G.; CRESTANI, M.; SPAVANELLO, R.; LORO, V. L.; BALDISSEROTTO, B. Ammonia and $\mathrm{pH}$ effects on some metabolic parameters and gill histology of silver catfish, Rhamdia quelen (Heptapteridae). Aquaculture, New York, v. 277, n. 3-4, p. 192-196, 2008.

PANKHURST, N. W. The endocrinology of stress in fish: an environmental perspective. General and Comparative Endocrinology, New York, v. 170, n. 2, p. 265-275, 2011.

PERSON-LE RUYET, J.; GALLAND, R.; LE ROUX, A.; CHARTOIS, H. Chronic ammonia toxicity in juvenile turbot (Scophthalmus maximus). Aquaculture, New York, v. 154, n. 1, p. 155-171, 1997.

RANDALL, D. J.; TSUI, T. K. N. Ammonia toxicity in fish. Marine Pollution Bulletin, New York, v. 45, n. 1, p. 17-23, 2002.

REYNALTE-TATAJE, D.; ZANIBONI FILHO, E. Cultivo de piapara, piauçu, piava e piau - gênero Leporinus. In: BALDISSEROTTO, B.; GOMES, L. C. (Ed.). Espécies nativas para piscicultura no Brasil. $2^{\text {th }}$ ed. Santa Maria: UFSM, 2010. cap. 3, p. 73-92.

RUYET, J. P. L.; CHARTOIS, H.; QUEMENER, L. Comparative acute ammonia toxicity in marine fish and plasma ammonia response. Aquaculture, New York, v. 136, n. 1, p. 181-194, 1995.

SAHA, N.; KHARBULI, Z. Y.; ARUNDHATI, B.; GOSWAMI, C.; HÄUSSINGER, D. Effect of alkalinity $(\mathrm{pH} 10)$ on ureogenesis in the air-breathing walking catfish, Clarias batrachus. Comparative Biochemistry and Physiology A, New York, v. 132, n. 2, p. 353-364, 2002.

SCHRAM, E.; ROQUES, J. A. C.; ABBINK, W.; SPANINGS, T.; DE VRIES, P.; BIERMAN, S.; VAN DE VIS, H.; FLIK, G. The impact of elevated water ammonia concentration on physiology, growth and feed intake of African catfish (Clarias gariepinus). Aquaculture, New York, v. 306, n. 1-4, p. 108-115, 2010.
SERAFINI, R. L.; ZANIBONI FILHO, E.; BALDISSEROTTO, B. Effect of combined non-ionized ammonia and dissolved oxygen levels on the survival of juvenile dourado, Salminus brasiliensis (Cuvier). Journal of the World Aquaculture Society, Hoboken, v. 40, n. 5, p. 695-701, 2009.

VERDOUW, H.; VANECHTELD, C. J. A.; DECKKERS, E. M. J. Ammonia determinations based on indophenol formation with sodium salicylate. Water Research, New York, v. 12, n. 6, p. 399-402, 1978.

VIDAL, E.; BASTOS, D. N.; OLIVEIRA, E. A.; BUTZGE, A. J.; MEWES, J. K.; BAUMGARTNER, G.; SANCHES, P. V.; BOMBARDELLI, R. A. Efeito da amônia sobre a fertilização artificial de ovócitos e no desenvolvimento inicial do jundiá cinza (Rhamdia quelen; Siluriformes, Heptapteridae). Semina Ciências Agrárias, Londrina, v. 34, n. 5, p. 2447-2456, 2013.

WALSH, P. J.; VEAUVY, C. M.; MCDONALD, M. D.; PAMENTER, M. E.; BUCK, L.; WILKIE, M. P. Piscine insights into comparisons of anoxia tolerance, ammonia toxicity, stroke and hepatic encephalopathy. Comparative Biochemistry and Physiology A, New York, v. 147, n. 2, p. 332-343, 2007.

WANG, Y.; WALSH, P. J. High ammonia tolerance in fishes of the family Batrachoididae (toadfish and midshipmen). Aquaculture Toxicology, New York, v. 50, n. 5, p. 205-219, 2000.

WENDELAAR BONGA, S. E. The stress response in fish. Physiology Review, Bethesda, v. 77, n. 3, p. 591$625,1997$.

WICKS, B. J.; RANDALL, D. J. The effect of sub-lethal ammonia exposure on fed and unfed rainbow trout: the role of glutamine in regulation ammonia. Comparative Biochemistry and Physiology A, New York, v. 132, n. 2, p. 275-285, 2002.

WRIGHT, P. A.; WOOD, C. M. Seven things fish know about ammonia and we don't. Respiratory Physiology and Neurobiology, New York, v. 184, n. 3, p. 231-240, 2012.

ZALL, D. M.; FISHER, M. D.; GARNER, Q. M. Photometric determination of chlorides in water. Analytical Chemistry, Washington, v. 28, n. 11, p. 16651678, 1956. 
